\title{
Cobalt(III) Complexes of Various Salen-Type Ligand Bearing Four Quaternary Ammonium Salts and Their Reactivity for $\mathrm{CO}_{2} /$ Epoxide Copolymerization
}

\author{
Bo Eun Kim, Jobi Kodiyan Varghese, Yonggyu Han, and Bun Yeoul Lee*
}

\author{
Department of Molecular Science and Technology, Ajou University, Suwon 443-749 Korea. *E-mail: bunyeoul@ajou.ac.kr \\ Received December 27, 2009, Accepted January 28, 2010
}

\begin{abstract}
Ligand variation was carried out on a cobalt(III) complex of Salen-type ligand comprised of 1,2-cyclohexenediamine and salicylaldehyde bearing a methyl substituent on 3-position and -[CMe $\left.\left(\mathrm{CH}_{2} \mathrm{CH}_{2} \mathrm{CH}_{2} \mathrm{~N}^{+} \mathrm{Bu}_{3}\right)_{2}\right]$ on 5-position, which is a highly active catalyst for $\mathrm{CO}_{2}$ /propylene oxide copolymerization. Replacement of the methyl substituent with bulky isopropyl group resulted in alteration of the binding mode, consequently lowering turnover frequency significantly. Replacement with an ethyl group preserved binding mode and activity. Replacement of the tributylammonium unit with trihexylammonium or trioctylammonium, or replacement of 1,2-cyclohexenediamino unit with $-\mathrm{NC}(\mathrm{Me})_{2} \mathrm{CH}_{2} \mathrm{~N}$ - decreased activity, even though the binding mode was unaltered.
\end{abstract}

Key Words: Carbon dioxide, Epoxide, Salen-cobalt complexes, Quaternary ammonium salt, Polymerization

\section{Introduction}

Recently, we disclosed a highly active catalytic system (1) for $\mathrm{CO}_{2}$ /propylene oxide (PO) copolymerization, which showed a high turnover number (TON) up to 20000 and a high turnover frequency (TOF) of $20000 \mathrm{~h}^{-1}$. It produced a strictly alternating copolymer with a high molecular weight $\left(\mathrm{M}_{\mathrm{n}}\right)$ of up to 300000 and a high selectivity (>99\%). Another advantage of 1 was that the catalyst was efficiently removed after polymerization from a polymer solution through filtration over a short pad of silica gel. The collected catalyst on the silica surface could then be recovered and reused. Catalyst residue removal is crucial for the copolymerization not only because the catalyst residue colors the resin but also because the residue is toxic and causes a severe thermal degradation during processing. ${ }^{2}$ These performances allow for the design of a continuous commercial process. The $\mathrm{CO}_{2} / \mathrm{PO}$ copolymer is attractive due to its favorable properties. ${ }^{3}$ Catalyst $\mathbf{1}$ was discovered while trying to develop a catalyst based on the concept of binding two components or two metal centers. ${ }^{4}$ The binding situated both components in close proximity regardless of the low catalyst concentration or high polymerization temperature to achieve a TON as well as high molecular weight. Later, we elucidated that the cobalt(III) complex adopted an unusual binding mode, where imine-nitrogens on the Salen-type ligand did not coordinate but, instead, the counter anions of the tethered quaternary ammonium coordinated to cobalt. ${ }^{5}$

The structure of the catalyst is a kind of supramolecular assembly working properly on the ion-ion interaction and hydrogen bonding, and the performances were highly sensitive to the ligand structure. For example, substituting hydrogen in $\mathbf{1}$ with methyl at a remote site from the reaction site (2) reduced the TOF from $20000 \mathrm{~h}^{-1}$ to $16000 \mathrm{~h}^{-1}$. Catalyst 2 could be prepared on a large scale while preparation of 1 was not easy. ${ }^{6}$ Replacing the cyclohexanediamino group with ethylenediamino group (3) reduced the TOF further to $8300 \mathrm{~h}^{-1}$. These observations prompted us to investigate thoroughly the influence of the ligand structure on the catalytic performances.

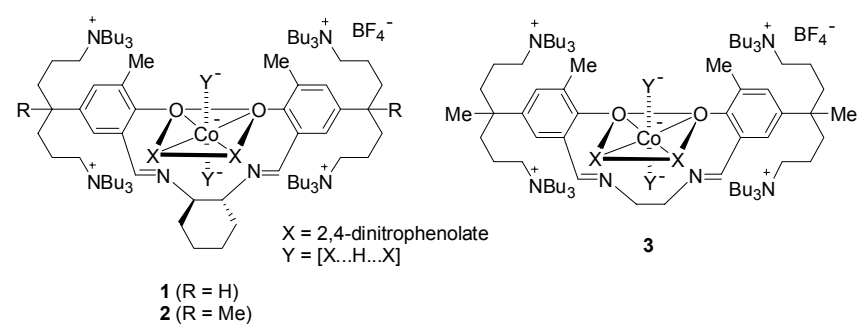

Chart 1. Salen-Co(III) catalysts for $\mathrm{CO}_{2}$ /epoxide copolymerization.

\section{Results and Discussion}

Synthesis and characterization. Variation was made on the ortho-substitutent of the Salen-phenoxy ligand. It was already revealed that bulky tert-butyl substituent on the ortho-position blocks formation of the imine uncoordinated binding mode of complexes $\mathbf{1}$ and $\mathbf{2}$. The complex bearing tert-butyl substituent was not highly active. Complexes bearing ethyl and isopropyl substituent were prepared according to the same synthetic route employed for the synthesis of 2 (Scheme 1). ${ }^{6}$ Thus, Friedel-Craft alkylation of 2-ethylphenol using 1,7-dichloro-4-methylheptan4-ol in the presence of $\mathrm{AlCl}_{3}$ produced compound 4 in $95 \%$ yield. In this reaction, 2-ethylphenol was used as both a reactant and a solvent, and no additional solvent was required. The excess 2-ethylphenol was recovered by vacuum distillation $\left(60^{\circ} \mathrm{C} /\right.$ $2 \mathrm{mmHg}$ ) and the remaining residue was pure $\mathbf{4}$ as determined by ${ }^{1} \mathrm{H}$ and ${ }^{13} \mathrm{C} \mathrm{NMR}$, and was amenable for the next reaction without further purification. Formylation of 4 using paraformaldehyde, triethylamine, and magnesium chloride was successful with good efficiency $(92 \%$ yield $){ }^{7}$ Because tributylamine could not attack chloroalkane, the chloro-compound was transformed into a more reactive iodo-compound $\mathbf{6}$ in $81 \%$ yield. After Salen-type ligand was generated from 6, tributylamine could attack the iodo-group yielding a Salen-type ligand containing four quaternary ammonium salts (8) in $86 \%$ yield. Because iodide anion intervenes in the metallation reaction, it was replaced with an inert $\mathrm{BF}_{4}^{-}$through treatment of $\mathrm{AgBF}_{4}$. 


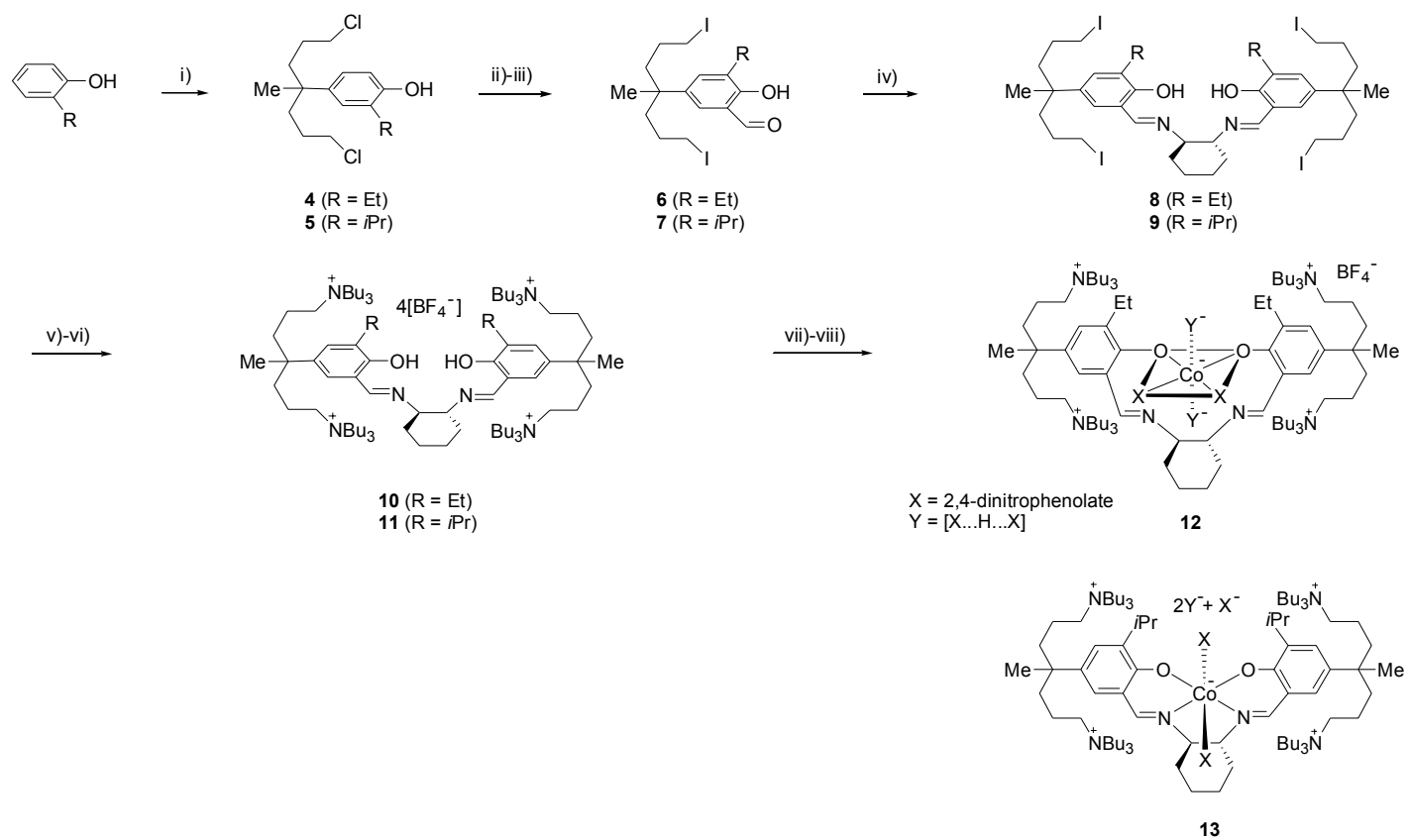

Scheme 1. i) 1,7-Dichloro-4-methylheptan-4-ol/ $\mathrm{AlCl}_{3}$; ii) Paraformaldehyde/ $\mathrm{NEt}_{3} / \mathrm{MgCl}_{2}$; iii) $\mathrm{NaI}$ in $\mathrm{CH}_{3} \mathrm{CN}$; iv) 1,2-Trans-diaminocyclohexane in $\mathrm{CH}_{2} \mathrm{Cl}_{2}$; v) $\mathrm{Bu}_{3} \mathrm{~N}$ in $\mathrm{CH}_{3} \mathrm{CN}$; vi) $\mathrm{AgBF}_{4}$; vii) $\mathrm{Co}(\mathrm{OAc})_{2}$ in ethanol; viii) $\mathrm{O}_{2}$ and 2,4-dinitrophenol in $\mathrm{CH}_{2} \mathrm{Cl}_{2}$, then $3\left[2,4-\left(\mathrm{NO}_{2}\right)_{2} \mathrm{C}_{6} \mathrm{H}_{3} \mathrm{O}\right) \mathrm{Na}_{3}+$ $2\left[2,4-\left(\mathrm{NO}_{2}\right)_{2} \mathrm{C}_{6} \mathrm{H}_{3} \mathrm{OH}\right]$
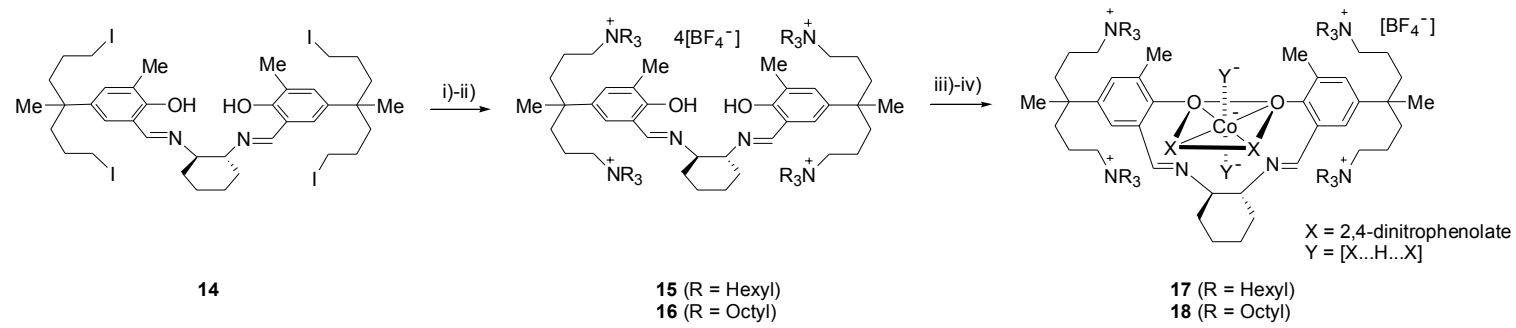

Scheme 2. i) Trihexylamine or trioctylamine in $\mathrm{CH}_{3} \mathrm{CN}$; ii) $\mathrm{AgBF}_{4}$; iii) $\mathrm{Co}(\mathrm{OAc})_{2}$ in ethanol; iv) $\mathrm{O}_{2}$ and 2,4-dinitrophenol in $\mathrm{CH}_{2} \mathrm{Cl}_{2}$, then $\left.3\left[2,4-\left(\mathrm{NO}_{2}\right)_{2} \mathrm{C}_{6} \mathrm{H}_{3} \mathrm{O}\right) \mathrm{Na}\right]+2\left[2,4-\left(\mathrm{NO}_{2}\right)_{2} \mathrm{C}_{6} \mathrm{H}_{3} \mathrm{OH}\right]$

Metallation was carried out by a routine method involving the treatment of $\mathrm{Co}(\mathrm{OAc})_{2}$ in ethanol and oxidation using $\mathrm{O}_{2}$ in the presence of an equivalent amount of 2,4-dinitrophenol. Finally, anion exchange reaction was carried out by stirring the $\mathrm{BF}_{4}{ }^{-}$ complex over a slurry of three equivalents of sodium 2,4-dinitrophenolate and two equivalents of 2,4-dinitrophenol in $\mathrm{CH}_{2} \mathrm{Cl}_{2}$. The Salen-aromatic signals were very broad at 7.87, 7.36 and $7.24 \mathrm{ppm}$ in the ${ }^{1} \mathrm{H}$ NMR spectrum of the final complex 12 in DMSO- $d_{6}$. Observation of broad Salen-aromatic signals in DMSO- $d_{6}$ was indicative of formation of the unusual imine uncoordinated binding mode. For the complex of the conventional imine coordinated Salen-complexes, the Salen-aromatic signals were sharp in DMSO- $d_{6}$. In THF- $d_{8}$, only two 2,4-dinitrophenolate signals per cobalt were observed at the region of $8.8 \sim 9.0 \mathrm{ppm}$, of which chemical shifts are significantly different from those of free 2,4-dinitrophenolate anion allowing assignment of the observed signals to the persistently coordinated two 2,4-dinitrophenolate. The remaining 2,4-dinitrophenol-2,4-dinitrophenolate homoconjugate was fluxional and the signals were missing due to severe broadening. Observation of the two 2,4-dinitrophenolate signals at the region of $8.8 \sim 9.0$ ppm was also an evidence for formation of the unusual imine uncoordinated binding mode.

Isopropyl complex 13 was also prepared by the same method and conditions employed for preparation of 12 (Scheme 1). In the ${ }^{1} \mathrm{H}$ NMR spectrum of 13 in DMSO- $d_{6}$, the Salen-aromatic signals were sharp at 7.83, 7.32, and 7.21 ppm as was observed for the tert-butyl complex, which was indicative of formation of the conventional imine coordinated binding mode. In THF- $d_{8}$, the characteristic coordinated 2,4-dinitrophenolate signals at $7.8 \sim 9.0 \mathrm{ppm}$ were not observed. Instead, very broad signals were observed in the aromatic region, which was also indicative of formation of the conventional imine coordinated binding mode.

In the binary catalytic system of [(Salen)Co-complexes]/ (quaternary ammonium salt), it was reported that the activity was improved by replacing the tetrabutylammonium salt with a more bulky tetraheptylammonium salt. ${ }^{8}$ So, we prepared the derivatives by variation of the ammonium salt unit (Scheme 2). Trioctylamine, trihexylamine, and tripropylamine attacked the iodo-group to generate the corresponding quaternary ammonium salts. After treatment of $\mathrm{AgBF}_{4}$ to replace the iodide anion 


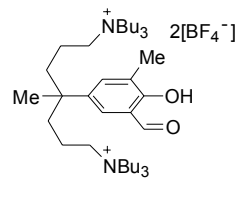

19

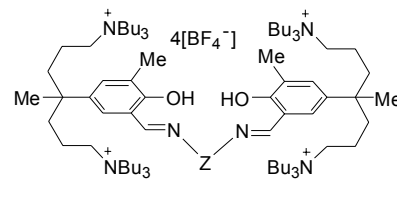

$20\left(\mathrm{Z}=-\mathrm{CMe}_{2} \mathrm{CH}_{2}-\right)$ $21\left(\mathrm{Z}=-\mathrm{CH}_{2} \mathrm{CH}_{2} \mathrm{CH}_{2}-\right)$

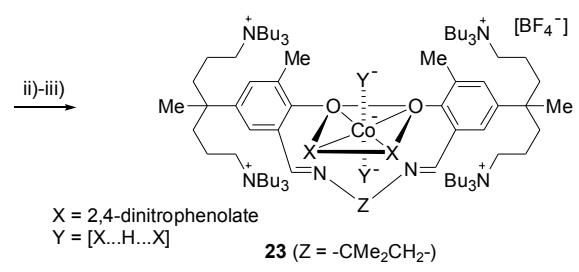

Scheme 3. i) $\mathrm{H}_{2} \mathrm{~N}-\mathrm{Z}-\mathrm{NH}_{2}$; ii) $\mathrm{Co}(\mathrm{OAc})_{2}$ in ethanol; iii) $\mathrm{O}_{2}$ and 2,4-dinitrophenol in $\mathrm{CH}_{2} \mathrm{Cl}_{2}$, then $\left.3\left[2,4-\left(\mathrm{NO}_{2}\right)_{2} \mathrm{C}_{6} \mathrm{H}_{3} \mathrm{O}\right) \mathrm{Na}\right]+2\left[2,4-(\mathrm{NO})_{2} \mathrm{C}_{6} \mathrm{H}_{3} \mathrm{OH}\right]$

with $\mathrm{BF}_{4}^{-}$, the product was purified by passing through a short pad of silica gel with a mixture of $\mathrm{CH}_{2} \mathrm{Cl}_{2}$ and ethanol $(\mathrm{v} / \mathrm{v}, 5: 1)$ to afford clean trihexylammonium salt (15) and trioctylammonium salt (16). In the case of tripropylammonium salt, the salt was destroyed during the chromatography. Metallations were carried out by the same method and condition applied for the preparation of $\mathbf{2}$ or 12. Observation of broad Salen-aromatic signals in the ${ }^{1} \mathrm{H}$ NMR spectra of 17 and 18 in DMSO- $d_{6}$ were indicative of formation of the unusual imine uncoordinated binding mode.

We attempted the variation of the cyclohexanediamino unit (Scheme 3). Compound 19 was prepared by the hydrolysis of the corresponding Salen-type ligand by the action of $\mathrm{HBF}_{4}{ }^{5(\mathrm{a})}$ Schiff bases 20-22 were generated quantitatively just by mixing the corresponding diamine and equivalent amount of 19. From ligand 20 containing $-\mathrm{NC}(\mathrm{Me})_{2} \mathrm{CH}_{2} \mathrm{~N}$ - unit, the desired complex 23 was obtained. In the ${ }^{1} \mathrm{H}$ NMR spectrum in DMSO- $d_{6}$, the Salen-phenoxy signals were broad indicating the unusual imine uncoordinated binding mode. In THF- $d_{8}$, two sets of sharp Salen-phenoxy signals were observed at 7.67, 7.56, 6.60, 6.60, 6.49 , and $6.39 \mathrm{ppm}$ along with the characteristic signals of the coordinated two 2,4-dinitrophenolate. From the ligands 21 and 22 containing $-\mathrm{CH}_{2} \mathrm{CH}_{2} \mathrm{CH}_{2}$ - and $-\mathrm{C}(\mathrm{Ph}) \mathrm{HC}(\mathrm{Ph}) \mathrm{H}$ - units, respectively, we failed in preparation of a clean complex. The signals in the ${ }^{1} \mathrm{H}$ NMR spectrum were very complicated and broad.

Polymerization studies. Complex 12 bearing ethyl substituent, which adopted the unusual imine uncoordinated binding mode, was highly active (TOF, $11000 \mathrm{~h}^{-1}$ ) for the $\mathrm{CO}_{2} / \mathrm{PO}$ copolymerization at conditions of $[\mathrm{PO}] /[\mathrm{Cat}]=50000,70 \sim 75^{\circ} \mathrm{C}$, and $\mathrm{P}_{\mathrm{CO}_{2}}=17 \sim 20$ bar (entry 1 in Table 1), while isopropyl 13 adopting the conventional imine coordinated structure exhibited significantly lower activity (TOF, $3200 \mathrm{~h}^{-1}$ ). This trend of an extraordinary high activity for the unusual binding mode is in agreement with the previous reports. ${ }^{5}$ The selectivity for the formation of polymer over cyclic carbonate was also excellent for the high active $\mathbf{1 2}$ (>99\%), but it was lowered (94\%) for the less active 13. However, the activity of the ethyl complex 12 was not better than that of the methyl complex 2 . The activity was also sensitive to the bulkiness of the ammonium salt. Replacing tributylammonium units with trihexylammonium ones resulted in lowering activity (TOF) from $15000 \mathrm{~h}^{-1}$ to $10000 \mathrm{~h}^{-1}$, and replacing with more bulky trioctylammonium units lowered the activity significantly to $6100 \mathrm{~h}^{-1}$ (entries 3-4 vs. entry 6). Reaction site of the cobalt center might be blocked by the bulky ammonium units to lower the activity. Replacing the cyclohexanediamino group with - $\mathrm{NC}(\mathrm{Me})_{2} \mathrm{CH}_{2} \mathrm{~N}$ - group also drama-
Table 1. $\mathrm{CO}_{2} /$ (propylene oxide) copolymerization results ${ }^{a}$

\begin{tabular}{|c|c|c|c|c|c|}
\hline Entry & Catalyst & $\operatorname{TOF}^{b}\left(\mathrm{~h}^{-1}\right)$ & Selectivity $^{c}$ & $\mathrm{M}_{\mathrm{n}}^{d} \times 10^{-3}$ & $\mathrm{M}_{\mathrm{w}} / \mathrm{M}_{\mathrm{n}}$ \\
\hline 1 & 12 & 11000 & $>99$ & 142 & 1.02 \\
\hline 2 & 13 & 3200 & 94 & 75 & 1.29 \\
\hline 3 & 17 & 10000 & $>99$ & 126 & 1.07 \\
\hline 4 & 18 & 6100 & 92 & 84 & 1.09 \\
\hline 5 & 23 & 3300 & 94 & 60 & 1.04 \\
\hline $6^{e}$ & 2 & 15000 & $>99$ & 270 & 1.26 \\
\hline
\end{tabular}

${ }^{a}$ Polymerization condition: $\mathrm{PO}(10 \mathrm{~g}, 170 \mathrm{mmol}),\left[\mathrm{PO} /[\mathrm{Cat}]=50000, \mathrm{CO}_{2}\right.$ $(2.0 \sim 1.7 \mathrm{MPa}), 70 \sim 75^{\circ} \mathrm{C}, 60$ minutes. ${ }^{b} \mathrm{Calculated}$ based on the weight of the isolated polymer including the cyclic carbonate. ${ }^{c}$ Selectivity of polycarbonate over cyclic carbonate in units of $\%$ as determined by ${ }^{1} \mathrm{H}$ NMR spectroscopy of the crude product. ${ }^{d}$ Determined on GPC using a polystyrene standard. ${ }^{e}$ Data from reference 5 .

tically decreased the activity from $15000 \mathrm{~h}^{-1}$ to $3300 \mathrm{~h}^{-1}$, even though the binding mode of $\mathbf{2 3}$ was identical with the cyclohexanediamino complex 2 (entry 5 vs. entry 6). Molecular weight distributions $\left(\mathrm{M}_{\mathrm{w}} / \mathrm{M}_{\mathrm{n}}\right)$ were narrow $(1.02 \sim 1.29)$ indicating an immortal polymerization.

\section{Summary}

Ligand variation was carried out on a cobalt(III) complex of Salen-type ligand comprised of 1,2-cyclohexenediamine and salicylaldehyde bearing a methyl substituent on 3-position and -[CMe $\left.\left(\mathrm{CH}_{2} \mathrm{CH}_{2} \mathrm{CH}_{2} \mathrm{~N}^{+} \mathrm{Bu}_{3}\right)_{2}\right]$ on 5-position, which is a highly active catalyst for $\mathrm{CO}_{2}$ /propylene oxide copolymerization. Replacement of the methyl substituent with bulky isopropyl group resulted in alteration of the binding mode from unusual imine uncoordinated structure to the conventional imine coordinated one, consequently lowering TOF significantly from $15000 \mathrm{~h}^{-1}$ to $3200 \mathrm{~h}^{-1}$. Replacement with ethyl group preserved binding mode and activity. Replacement of tributylammonium unit with trihexylammonium and trioctylammonium or replacement of 1,2-cyclohexenediamino unit with - $\mathrm{NC}(\mathrm{Me})_{2} \mathrm{CH}_{2} \mathrm{~N}$ - also reduced the activity to $10000 \mathrm{~h}^{-1}, 6100 \mathrm{~h}^{-1}$, and $3300 \mathrm{~h}^{-1}$, respectively, even though the binding mode was unaltered.

\section{Experimental Section}

General remarks. All manipulations were performed under an inert atmosphere using standard glove box and Schlenk techniques. THF and $\mathrm{C}_{6} \mathrm{D}_{6}$ were distilled from benzophenone ketyl. 
Ethanol was dried as previously described using sodium and diethyl phthalate. ${ }^{9} \mathrm{CH}_{3} \mathrm{CN}, \mathrm{CH}_{2} \mathrm{Cl}_{2}$, and $\mathrm{CDCl}_{3}$ were dried by stirring over $\mathrm{CaH}_{2}$, and were subsequently vacuum-transferred to reservoirs. The $\mathrm{CO}_{2}$ gas $(99.999 \%)$ was dried by storing in a column of molecular sieves $3 \mathrm{~A}$ at 30 bar. Propylene oxide (PO) was dried by stirring over $\mathrm{CaH}_{2}$ for several days, and it was vacuum-transferred to a reservoir. The ${ }^{1} \mathrm{H} \mathrm{NMR}(400 \mathrm{MHz})$ and ${ }^{13} \mathrm{C}$ NMR $(100 \mathrm{MHz})$ spectra were recorded on a Varian Mercury Plus 400. Gel permeation chromatograms (GPC) were obtained at room temperature in chloroform using Waters Millennium with polystyrene standards. Compounds 14 and 19 were prepared by the method reported previously in the literature. $^{6,5(\mathrm{a})}$

Compound 4. 2-Ethylphenol (4.91 g, $40.2 \mathrm{mmol})$, 1,7-dichloro-4-methylheptan-4-ol (1.00 g, $5.02 \mathrm{mmol})$, and $\mathrm{AlCl}_{3}$ $(0.736 \mathrm{~g}, 5.52 \mathrm{mmol})$ were mixed and the mixture was stirred overnight under an atmosphere of $\mathrm{N}_{2}$. The reaction was quenched by the addition of diethyl ether $(25 \mathrm{~mL})$ and water $(15 \mathrm{~mL})$. The organic phase was collected and the water phase was further extracted with additional diethyl ether $(3 \times 25 \mathrm{~mL})$. After the combined diethyl ether was dried over anhydrous $\mathrm{MgSO}_{4}$, the solvent was removed with a rotary evaporator. The excess 2-ethylphenol was recovered by vacuum distillation $\left(60{ }^{\circ} \mathrm{C} /\right.$ $2 \mathrm{mmHg}$ ). Yellowish oily product was obtained (1.49 g, 95\%). IR $(\mathrm{KBr}) 3289(\mathrm{OH}) \mathrm{cm}^{-1}$. ${ }^{1} \mathrm{H} \mathrm{NMR}\left(\mathrm{CDCl}_{3}\right) \delta 7.03(\mathrm{~d}, J=2.0$ $\mathrm{Hz}, 1 \mathrm{H}, m-\mathrm{H}), 6.96(\mathrm{dd}, J=8.0 \mathrm{~Hz}, 2.0 \mathrm{~Hz}, 1 \mathrm{H}, m-\mathrm{H}), 6.71(\mathrm{~d}$, $J=8.0 \mathrm{~Hz}, 1 \mathrm{H}, o-\mathrm{H}), 4.71(\mathrm{~s}, 1 \mathrm{H}, \mathrm{OH}), 3.45(\mathrm{t}, J=6.4 \mathrm{~Hz}, 4 \mathrm{H}$, $\left.\mathrm{CH}_{2} \mathrm{Cl}\right), 2.75\left(\mathrm{q}, J=7.6 \mathrm{~Hz}, 2 \mathrm{H}, \mathrm{CH}_{2}\right), 1.80-1.42\left(\mathrm{~m}, 8 \mathrm{H}, \mathrm{CH}_{2}\right)$, $1.33\left(\mathrm{~s}, 3 \mathrm{H}, \mathrm{CH}_{3}\right), 1.28\left(\mathrm{t}, J=7.6 \mathrm{~Hz}, 3 \mathrm{H}, \mathrm{CH}_{3}\right)$. HRMS (EI) $m / z$ calcd $\left(\mathrm{M}^{+} \mathrm{C}_{16} \mathrm{H}_{24} \mathrm{Cl}_{2} \mathrm{O}\right) 302.1246$, found 302.1248 .

Compound 5. This compound was synthesized using the same conditions and procedure as compound 4 starting with 2-isopropylphenol. Yellowish oily product was obtained in $92 \%$ yield. IR (KBr) $3294(\mathrm{OH}) \mathrm{cm}^{-1}$. ${ }^{1} \mathrm{H}$ NMR $\left(\mathrm{CDCl}_{3}\right) \delta 7.09(\mathrm{~d}, J=2.0$ $\mathrm{Hz}, 1 \mathrm{H}, m-\mathrm{H}), 6.95(\mathrm{dd}, J=8.0 \mathrm{~Hz}, 2.0 \mathrm{~Hz}, 1 \mathrm{H}, m-\mathrm{H}), 6.68(\mathrm{~d}$, $J=8.0 \mathrm{~Hz}, 1 \mathrm{H}, o-\mathrm{H}), 4.68(\mathrm{~s}, 1 \mathrm{H}, \mathrm{OH}), 3.45(\mathrm{t}, J=6.4 \mathrm{~Hz}, 4 \mathrm{H}$, $\mathrm{CH}_{2} \mathrm{Cl}$ ), 3.21 (septet, $\left.1 \mathrm{H}, \mathrm{CH}\right), 1.90-1.45\left(\mathrm{~m}, 8 \mathrm{H}, \mathrm{CH}_{2}\right), 1.29$ $\left(\mathrm{s}, 3 \mathrm{H}, \mathrm{CH}_{3}\right), 1.27\left(\mathrm{~d}, J=6.0 \mathrm{~Hz}, 6 \mathrm{H}, \mathrm{CH}_{3}\right) .{ }^{13} \mathrm{C}\left\{{ }^{1} \mathrm{H}\right\} \mathrm{NMR}$ $\left(\mathrm{CDCl}_{3}\right) \delta 151.34,139.43,134.76,125.23,125.09,115.79$, 46.89, 41.77, 40.91, 28.77, 28.37, 25.03, 23.79. HRMS (EI) $m / z$ calcd $\left(\mathrm{M}^{+} \mathrm{C}_{17} \mathrm{H}_{26} \mathrm{Cl}_{2} \mathrm{O}\right)$ 316.1426, found 316.1427.

Compound 6. Compound 4 (1.30 g, $4.30 \mathrm{mmol})$ was dissolved in anhydrous THF $(30 \mathrm{~mL})$. Paraformaldehyde $(0.517 \mathrm{~g}$, $17.2 \mathrm{mmol})$, triethylamine (1.83 g, $18.1 \mathrm{mmol})$ and magnesium chloride (1.64 g, $17.2 \mathrm{mmol}$ ) were added under a $\mathrm{N}_{2}$ atmosphere. The reaction mixture was heated to reflux for 5 hours and cooled to room temperature. The solvent was removed with a rotary evaporator. Water $(15 \mathrm{~mL})$ and $\mathrm{CH}_{2} \mathrm{Cl}_{2}(25 \mathrm{~mL})$ were added to the residue, and the mixture was filtered over Celite. The organic phase was collected, and the aqueous phase was further extracted using $\mathrm{CH}_{2} \mathrm{Cl}_{2}(2 \times 15 \mathrm{~mL})$. The combined organic phase was dried over anhydrous $\mathrm{MgSO}_{4}$. The solvent was removed with a rotary evaporator to give an oily residue that was evacuated further to remove some residual triethylamine. The residue was dissolved in $\mathrm{CH}_{3} \mathrm{CN}(6 \mathrm{~mL})$ and $\mathrm{NaI}(6.49 \mathrm{~g}$, $43.3 \mathrm{mmol}$ ) was added. After the resulting mixture was refluxed for 20 hours, it was cooled to room temperature. After water $(15 \mathrm{~mL})$ was added, the product was extracted using diethyl ether $(3 \times 15 \mathrm{~mL})$. After the collected organic phase was dried over anhydrous $\mathrm{MgSO}_{4}$, all volatiles were removed with a rotary evaporator to give yellow oil. The product was purified by column chromatography on silica gel, eluting with hexane and ethyl acetate (v/v, 20:1). The yield was $81 \%(1.8 \mathrm{~g})$. IR $(\mathrm{KBr}) 3258(\mathrm{OH}), 1649(\mathrm{C}=\mathrm{O}) \mathrm{cm}^{-1} .{ }^{1} \mathrm{H}$ NMR $\left(\mathrm{CDCl}_{3}\right) \delta 11.15$ (s, 1H, OH), $9.87(\mathrm{~s}, 1 \mathrm{H}, \mathrm{CHO}) 7.35(\mathrm{~s}, 1 \mathrm{H}, m-\mathrm{H}), 7.24(\mathrm{~s}, 1 \mathrm{H}$, $m-\mathrm{H}), 3.12\left(\mathrm{~m}, 4 \mathrm{H}, \mathrm{CH}_{2} \mathrm{I}\right), 2.71\left(\mathrm{q}, J=7.6 \mathrm{~Hz}, 2 \mathrm{H}, \mathrm{CH}_{2}\right), 1.90-$ $1.40\left(\mathrm{~m}, 8 \mathrm{H}, \mathrm{CH}_{2}\right), 1.34$ (s, 3H, $\left.\mathrm{CH}_{3}\right), 1.26(\mathrm{t}, J=7.6 \mathrm{~Hz}, 3 \mathrm{H}$, $\left.\mathrm{CH}_{3}\right) .{ }^{13} \mathrm{C}\left\{{ }^{1} \mathrm{H}\right\} \mathrm{NMR}\left(\mathrm{CDCl}_{3}\right) \delta 196.92,157.97,137.60,134.59$, 132.93, 128.85, 119.75, 44.27, 40.05, 28.64, 24.26, 23.05, 14.41, 8.06. HRMS (EI) $m / z$ calcd $\left(\mathrm{M}^{+} \mathrm{C}_{17} \mathrm{H}_{24} \mathrm{I}_{2} \mathrm{O}_{2}\right)$ 513.9931, found 513.9931 .

Compound 7. This compound was synthesized using the same conditions and procedure as compound $\mathbf{6}$ starting with $\mathbf{5}$. Yield was 86\%. IR (KBr) $3289(\mathrm{OH}), 1651(\mathrm{C}=\mathrm{O}) \mathrm{cm}^{-1} .{ }^{1} \mathrm{H}$ $\mathrm{NMR}\left(\mathrm{CDCl}_{3}\right) \delta 11.25(\mathrm{~s}, 1 \mathrm{H}, \mathrm{OH}), 9.86(\mathrm{~s}, 1 \mathrm{H}, \mathrm{CHO}) 7.41(\mathrm{~s}$, $1 \mathrm{H}, m-\mathrm{H}), 7.23(\mathrm{~s}, 1 \mathrm{H}, m-\mathrm{H}), 3.38$ (septet, $1 \mathrm{H}, \mathrm{CH}), 3.13(\mathrm{~m}$, $\left.4 \mathrm{H}, \mathrm{CH}_{2} \mathrm{I}\right), 1.94-1.42\left(\mathrm{~m}, 8 \mathrm{H}, \mathrm{CH}_{2}\right), 1.35\left(\mathrm{~s}, 3 \mathrm{H}, \mathrm{CH}_{3}\right), 1.28$ (d, $\left.J=6.0 \mathrm{~Hz}, 6 \mathrm{H}, \mathrm{CH}_{3}\right) .{ }^{13} \mathrm{C}\left\{{ }^{1} \mathrm{H}\right\} \mathrm{NMR}\left(\mathrm{CDCl}_{3}\right) \delta 197.01,157.58$, 137.54, 137.24, 131.87, 128.76, 119.77, 44.28, 40.18, 28.60, 27.01, 24.34, 22.81, 8.12. HRMS (EI) $m / z$ calcd $\left(\mathrm{M}^{+} \mathrm{C}_{18} \mathrm{H}_{26} \mathrm{I}_{2} \mathrm{O}_{2}\right)$ 528.0032 , found 528.0030 .

Compound 8. Compound $6(1.73 \mathrm{~g}, 3.37 \mathrm{mmol})$ and $( \pm)$-trans1,2-diaminocyclohexane $(0.192 \mathrm{~g}, 1.69 \mathrm{mmol})$ were weighed into a one-neck flask, and then $\mathrm{CH}_{2} \mathrm{Cl}_{2}(20 \mathrm{~mL})$ and small amount of molecular sieves were added. The solution was stirred overnight under a $\mathrm{N}_{2}$ atmosphere. The solvent was removed under vacuum to give a pure yellow compound (1.82 g, 98\%). IR $(\mathrm{KBr}) 3447(\mathrm{OH}), 1628(\mathrm{C}=\mathrm{N}) \mathrm{cm}^{-1} .{ }^{1} \mathrm{H} \mathrm{NMR}\left(\mathrm{CDCl}_{3}\right) \delta$ $13.44(\mathrm{~s}, 2 \mathrm{H}, \mathrm{OH}), 8.33(\mathrm{~s}, 2 \mathrm{H}, \mathrm{CH}=\mathrm{N}), 7.07(\mathrm{~s}, 2 \mathrm{H}, m-\mathrm{H}), 6.92$ $(\mathrm{s}, 2 \mathrm{H}, m-\mathrm{H}), 3.38-3.36(\mathrm{~m}, 2 \mathrm{H}$, cyclohexyl-CH), 3.16-3.04 (m, $\left.8 \mathrm{H}, \mathrm{CH}_{2} \mathrm{I}\right), 2.70-2.64\left(\mathrm{~m}, 4 \mathrm{H}, \mathrm{CH}_{2}\right), 1.98-1.84$ (m, 4H, cyclohexyl- $\left.\mathrm{CH}_{2}\right), 1.84-1.40\left(\mathrm{~m}, 20 \mathrm{H}\right.$, cyclohexyl- $\mathrm{CH}_{2}$ and $\left.\mathrm{CH}_{2}\right), 1.30$ $\left(\mathrm{m}, 12 \mathrm{H}, \mathrm{Et}-\mathrm{CH}_{3}\right.$ and $\left.\mathrm{CH}_{3}\right) .{ }^{13} \mathrm{C}\left\{{ }^{1} \mathrm{H}\right\} \mathrm{NMR}\left(\mathrm{CDCl}_{3}\right) \delta 165.07$, 156.97, 136.16, 131.54, 129.70, 126.87, 117.74, 72.81, 44.36, 39.83, 33.72, 28.60, 24.40, 24.41, 14.59, 8.52. Anal. Calcd. $\left(\mathrm{C}_{40} \mathrm{H}_{58} \mathrm{I}_{4} \mathrm{~N}_{2} \mathrm{O}_{2}\right): \mathrm{C}, 43.42 ; \mathrm{H}, 5.28 ; \mathrm{N}, 2.53 \%$. Found: C, 42.43; $\mathrm{H}, 5.25 ; \mathrm{N}, 2.51 \%$.

Compound 9. This compound was synthesized using the same conditions and procedure as compound 8 starting with 7. Yield was 97\%. IR (KBr) $3437(\mathrm{OH}), 1628(\mathrm{C}=\mathrm{N}) \mathrm{cm}^{-1} .{ }^{1} \mathrm{H}$ $\operatorname{NMR}\left(\mathrm{CDCl}_{3}\right) \delta 13.53(\mathrm{~s}, 2 \mathrm{H}, \mathrm{OH}), 8.35(\mathrm{~s}, 2 \mathrm{H}, \mathrm{CH}=\mathrm{N}), 7.14$ (s, 2H, $m-\mathrm{H}), 6.92(\mathrm{~s}, 2 \mathrm{H}, m-\mathrm{H}), 3.44-3.31(\mathrm{~m}, 4 \mathrm{H}, i \mathrm{Pr}-\mathrm{CH}$ and cyclohexyl-CH), 3.14-3.04 (m, 8H, $\left.\mathrm{CH}_{2} \mathrm{I}\right), 1.98-1.84(\mathrm{~m}, 4 \mathrm{H}$, cyclohexyl- $\left.\mathrm{CH}_{2}\right), 1.84-1.40\left(\mathrm{~m}, 20 \mathrm{H}\right.$, cyclohexyl- $\mathrm{CH}_{2}$ and $\left.\mathrm{CH}_{2}\right)$, $1.28\left(\mathrm{~d}, J=6.0 \mathrm{~Hz}, 12 \mathrm{H}, i \operatorname{Pr}-\mathrm{CH}_{3}\right), 1.26\left(\mathrm{~s}, 6 \mathrm{H}, \mathrm{CH}_{3}\right) .{ }^{13} \mathrm{C}\left\{{ }^{1} \mathrm{H}\right\}$ $\operatorname{NMR}\left(\mathrm{CDCl}_{3}\right) \delta 165.16,156.54,136.08,135.91,126.81,126.75$, 117.73, 72.72, 44.24, 39.95, 33.76, 28.63, 27.08, 24.51, 22.97, 8.42. Anal. Calcd. $\left(\mathrm{C}_{42} \mathrm{H}_{62} \mathrm{I}_{4} \mathrm{~N}_{2} \mathrm{O}_{2}\right)$ : C, 44.46; $\mathrm{H}, 5.51 ; \mathrm{N}, 2.47 \%$. Found: C, 44.53; H, 5.11; N, 2.42\%.

Compound 10. Compound 8 (1.45 g, $1.32 \mathrm{mmol})$ and tributylamine $(1.01 \mathrm{~g}, 5.43 \mathrm{mmol})$ were weighed into a one-neck flask, and $\mathrm{CH}_{3} \mathrm{CN}(15 \mathrm{~mL})$ was added. The solution was refluxed for 2 days under a $\mathrm{N}_{2}$ atmosphere. After the solution was cooled to room temperature, the solvent was removed under vacuum to give a residue that was subsequently triturated three times in diethyl ether $(3 \mathrm{~mL})$ to give a light yellow powder in 
$99 \%$ yield. To a flask containing this yellow powder $(2.42 \mathrm{~g}$, $1.31 \mathrm{mmol}), \mathrm{AgBF}_{4}(1.02 \mathrm{~g}, 5.24 \mathrm{mmol})$ and $\mathrm{CH}_{2} \mathrm{Cl}_{2}(25 \mathrm{~mL})$ was added. The solution was stirred for a day in the dark. AgI generated as a grey precipitate was filtered off over Celite inside a glove box. The solvent was removed under vacuum to yield a yellow residue that was subsequently purified by column chromatography on a short pad of silica gel, eluting with ethanol and $\mathrm{CH}_{2} \mathrm{Cl}_{2}$ (v/v, 1:5). The yield was $1.78 \mathrm{~g}(82 \%)$. IR (KBr) 3440 $(\mathrm{OH}), 1627(\mathrm{C}=\mathrm{N}) \mathrm{cm}^{-1} .{ }^{1} \mathrm{H} \mathrm{NMR}\left(\mathrm{CDCl}_{3}\right) \delta 13.57(\mathrm{~s}, 2 \mathrm{H}, \mathrm{OH})$, $8.44(\mathrm{~s}, 2 \mathrm{H}, \mathrm{CH}=\mathrm{N}), 7.10$ (s, 4H, $m-\mathrm{H}), 3.40$ (br, 2H, cyclohexyl$\mathrm{CH}), 3.09$ (br, 32H, $\mathrm{NCH}_{2}$ ), 2.64 (br, 4H, Et-CH 2 ), 1.94-1.84 (br, 4H, cyclohexyl- $\mathrm{CH}_{2}$ ), 1.84-1.22 (br, 74H, cyclohexyl- $\mathrm{CH}_{2}$ and $\left.\mathrm{CH}_{2}\right), 1.19\left(\mathrm{t}, J=7.6 \mathrm{~Hz}, 6 \mathrm{H}, \mathrm{Et}-\mathrm{CH}_{3}\right), 0.99-0.82(\mathrm{t}, J=$ $\left.6.8 \mathrm{~Hz}, 36 \mathrm{H}, \mathrm{CH}_{3}\right) .{ }^{13} \mathrm{C}\left\{{ }^{1} \mathrm{H}\right\} \mathrm{NMR}\left(\mathrm{CDCl}_{3}\right) \delta 165.32,157.45$, $135.58,131.83,129.69,127.16,118.11,72.19,59.34,58.66$, 40.17, 37.66, 25.04, 23.96, 23.55, 19.86, 17.36, 14.73, 13.85 . Anal. Calcd. $\left(\mathrm{C}_{88} \mathrm{H}_{166} \mathrm{~B}_{4} \mathrm{~F}_{16} \mathrm{~N}_{6} \mathrm{O}_{2}\right)$ : C, 62.63; H, 9.92; N, 4.98\%. Found: C, 62.42; H, 9.61; N, 4.54\%.

Compound 11. This compound was synthesized using the same conditions and procedure as compound $\mathbf{1 0}$ starting with 9. Yield was $80 \%$. IR $(\mathrm{KBr}) 3437(\mathrm{OH}), 1628(\mathrm{C}=\mathrm{N}) \mathrm{cm}^{-1} .{ }^{1} \mathrm{H}$ $\mathrm{NMR}\left(\mathrm{CDCl}_{3}\right) \delta 13.66(\mathrm{~s}, 2 \mathrm{H}, \mathrm{OH}), 8.46(\mathrm{~s}, 2 \mathrm{H}, \mathrm{CH}=\mathrm{N}), 7.11$ (s, 2H, $m-\mathrm{H}), 7.10$ (s. 2H, $m-\mathrm{H}), 3.39$ (br, 2H, cyclohexyl-CH), 3.28 (sept, $J=6.8 \mathrm{~Hz}, 2 \mathrm{H}, \mathrm{CH}-i \mathrm{Pr}$ ), 3.04 (br, $32 \mathrm{H}, \mathrm{NCH}_{2}$ ), 1.96$1.21(\mathrm{br}, 84 \mathrm{H}), 0.85\left(\mathrm{t}, J=6.8 \mathrm{~Hz}, 36 \mathrm{H}, \mathrm{CH}_{3}\right) .{ }^{13} \mathrm{C}\left\{{ }^{1} \mathrm{H}\right\} \mathrm{NMR}$ $\left(\mathrm{CDCl}_{3}\right) \delta 165.47,157.02,136.08,135.48,127.04,126.65$, 118.11, 71.98, 59.35, 58.67, 40.37, 37.91, 27.27, 24.84, 24.00, 22.88, 19.89, 17.38, 13.88. Anal. Calcd. $\left(\mathrm{C}_{90} \mathrm{H}_{170} \mathrm{~B}_{4} \mathrm{~F}_{16} \mathrm{~N}_{6} \mathrm{O}_{2}\right)$ : C, 63.01; H, 9.99; N, 4.90\%. Found: C, 63.24; H, 9.72; N, 4.72\%.

Complex 12. Complex $9(83 \mathrm{mg}, 0.050 \mathrm{mmol})$ and $\mathrm{Co}(\mathrm{OAc})_{2}$ $(8.9 \mathrm{mg}, 0.050 \mathrm{mmol})$ were added into a vial and anhydrous ethanol $(2.0 \mathrm{~mL})$ was added. After the solution was stirred for 3 hours at room temperature, the solvent was removed under a vacuum to give a residue, which was washed with diethyl ether $(2 \mathrm{~mL} \times 2)$. The solid was dissolved in $\mathrm{CH}_{2} \mathrm{Cl}_{2}(2 \mathrm{~mL})$ containing 2,4-dinitrophenol (9 $\mathrm{mg}, 0.05 \mathrm{mmol})$, and the solution was stirred under an $\mathrm{O}_{2}$ atmosphere for 3 hours. A mixture of three equivalents of sodium-2,4-dinitrophenolate and two equivalents of 2,4-dinitrophenol was added. After the solution was stirred overnight at room temperature, it was filtered over Celite. The solvent was removed under vacuum to give a dark brown powder that was pure enough to be used for polymerization. Yield was quantitative. ${ }^{1} \mathrm{H}$ NMR (DMSO- $\left.d_{6}, 40{ }^{\circ} \mathrm{C}\right) \delta 8.62(\mathrm{br}$, $\left.5 \mathrm{H},\left(\mathrm{NO}_{2}\right)_{2} \mathrm{C}_{6} \mathrm{H}_{3} \mathrm{O}\right), 7.98\left(\mathrm{br}, 5 \mathrm{H},\left(\mathrm{NO}_{2}\right)_{2} \mathrm{C}_{6} \mathrm{H}_{3} \mathrm{O}\right), 7.87(\mathrm{~s}, 2 \mathrm{H}$, $\mathrm{CH}=\mathrm{N}), 7.36(\mathrm{~s}, 2 \mathrm{H}, m-\mathrm{H}), 7.24(\mathrm{~s}, 2 \mathrm{H}, m-\mathrm{H}), 6.69(\mathrm{br}, 5 \mathrm{H}$, $\left(\mathrm{NO}_{2}\right)_{2} \mathrm{C}_{6} \mathrm{H}_{3} \mathrm{O}$ ), 3.75 (br s, $2 \mathrm{H}, \mathrm{NCH}_{2}$ bridged), 3.30-2.88 (br, $32 \mathrm{H}, \mathrm{NCH}_{2}$ ), 2.51 (br, 4H, Et- $\mathrm{CH}_{2}$ ), 2.05-1.85 (br, 4H, cyclohexyl- $\left.\mathrm{CH}_{2}\right), 1.70-1.40(\mathrm{br}, 80 \mathrm{H}), 0.86\left(\mathrm{t}, J=6.4 \mathrm{~Hz}, 36 \mathrm{H}, \mathrm{CH}_{3}\right)$. ${ }^{13} \mathrm{C}\left\{{ }^{1} \mathrm{H}\right\}$ NMR (DMSO- $\left.d_{6}\right) \delta 162.12,159.88,135.40,135.71$, $129.77,128.56,127.69,122.32,116.55,68.30,57.12,56.55$, $38.11,37.47,28.47,23.30,22.46,21.96,18.07,15.74,13.78$, 12.20 .

Complex 13. This compound was synthesized using the same conditions and procedure as complex 12 starting with 10. Dark brown powder was obtained in quantitative yield. ${ }^{1} \mathrm{H}$ NMR (DMSO- $\left.d_{6}, 40^{\circ} \mathrm{C}\right) \delta 8.87\left(\mathrm{br}, 5 \mathrm{H},\left(\mathrm{NO}_{2}\right)_{2} \mathrm{C}_{6} \mathrm{H}_{3} \mathrm{O}\right), 8.30$ (br, $\left.5 \mathrm{H},\left(\mathrm{NO}_{2}\right)_{2} \mathrm{C}_{6} \mathrm{H}_{3} \mathrm{O}\right), 7.83(\mathrm{~s}, 2 \mathrm{H}, \mathrm{CH}=\mathrm{N}), 7.32(\mathrm{~s}, 2 \mathrm{H}, m-\mathrm{H})$, $7.21(\mathrm{~s}, 2 \mathrm{H}, m-\mathrm{H}), 7.05$ (br, $\left.5 \mathrm{H},\left(\mathrm{NO}_{2}\right)_{2} \mathrm{C}_{6} \mathrm{H}_{3} \mathrm{O}\right), 4.08$ (br, $2 \mathrm{H}$, $i$ Pr-CH), 3.64 (br, 2H, $\mathrm{NCH}_{2}$ bridged), 3.30-2.80 (br, 32H, $\mathrm{NCH}_{2}$ ), 2.09-1.75 (br, 4H, cyclohexyl- $\mathrm{CH}_{2}$ ), 1.70-1.12 (br, $\left.86 \mathrm{H}\right)$, $0.86\left(\mathrm{t}, J=6.4 \mathrm{~Hz}, 36 \mathrm{H}, \mathrm{CH}_{3}\right) .{ }^{13} \mathrm{C}\left\{{ }^{1} \mathrm{H}\right\} \mathrm{NMR}$ (DMSO- $\left.d_{6}\right) \delta$ 159.27, 147.23, 146.16, 139.79, 131.67, 130.49, 128.29, 122.67, $118.61,116.77,68.21,57.07,56.52,38.20,37.49,28.45,23.32$, 22.41, 21.94, 21.63, 21.03, 18.06, 15.74, 12.24.

Compound 15. Compound $14(0.270 \mathrm{~g}, 0.250 \mathrm{mmol})$ and trihexylamine $(0.276 \mathrm{~g}, 1.03 \mathrm{mmol})$ were weighed into a oneneck flask, and $\mathrm{CH}_{3} \mathrm{CN}(5 \mathrm{~mL})$ was added. The solution was refluxed for 2 days under a $\mathrm{N}_{2}$ atmosphere. After the solution was cooled to room temperature, the solvent was removed under vacuum to give a residue that was subsequently triturated three times in pentane $(2 \mathrm{~mL})$ then dried to give light yellow powder over $99 \%$ yield. To a flask containing this yellow powder $(0.320 \mathrm{~g}, 0.150 \mathrm{mmol})$ and $\mathrm{AgBF}_{4}(0.116 \mathrm{mg}, 0.600 \mathrm{mmol})$, $\mathrm{CH}_{2} \mathrm{Cl}_{2}$ (3 mL) was added. The solution was stirred for a day in the dark. AgI generated as a grey precipitate was filtered off over Celite inside a glove box, the solvent was removed under vacuum to yield a yellow residue that was subsequently purified by column chromatography on a short pad of silica gel, eluting with ethanol and $\mathrm{CH}_{2} \mathrm{Cl}_{2}(\mathrm{v} / \mathrm{v}, 1: 5)$. Yield was $95 \%(0.284 \mathrm{~g})$. IR $(\mathrm{KBr}) 3445(\mathrm{OH}), 1629(\mathrm{C}=\mathrm{N}) \mathrm{cm}^{-1} .{ }^{1} \mathrm{H} \mathrm{NMR}\left(\mathrm{CDCl}_{3}\right) \delta$ $13.57(\mathrm{~s}, 2 \mathrm{H}, \mathrm{OH}), 8.44(\mathrm{~s}, 2 \mathrm{H}, \mathrm{CH}=\mathrm{N}), 7.26(\mathrm{~s}, 2 \mathrm{H}, m-\mathrm{H}), 7.17$ (s. $2 \mathrm{H}, m-\mathrm{H}), 3.53$ (br, $2 \mathrm{H}$, cyclohexyl-CH), 3.40-3.15 (br, $32 \mathrm{H}$, $\left.\mathrm{NCH}_{2}\right), 2.27\left(\mathrm{~s}, 6 \mathrm{H}, \mathrm{CH}_{3}\right), 2.04-1.20(\mathrm{br}, 126 \mathrm{H}), 0.88(\mathrm{t}, J=$ $\left.6.4 \mathrm{~Hz}, 36 \mathrm{H}, \mathrm{CH}_{3}\right) .{ }^{13} \mathrm{C}\left\{{ }^{1} \mathrm{H}\right\} \mathrm{NMR}\left(\mathrm{CDCl}_{3}\right) \delta 164.91,157.57$, 135.19, 130.86, 126.97, 125.50, 117.79, 72.36, 68.07, 59.09, 58.63, 39.87, 37.21, 31.22, 25.98, 25.80, 24.97, 22.57, 21.86, 17.17, 15.91, 14.12. Anal. Calcd. $\left(\mathrm{C}_{108} \mathrm{H}_{206} \mathrm{~B}_{4} \mathrm{~F}_{16} \mathrm{~N}_{6} \mathrm{O}_{2}\right)$ : C, 65.91; H, 10.55; N, 4.27\%. Found: C, 65.62; H, 10.75; N, 4.24\%.

Compound 16. This compound was synthesized using the same conditions and procedure as compound 15 using trioctylamine. Yield was 97\%. IR (KBr) $3447(\mathrm{OH}), 1635(\mathrm{C}=\mathrm{N}) \mathrm{cm}^{-1}$. ${ }^{1} \mathrm{H}$ NMR $\left(\mathrm{CDCl}_{3}\right) \delta 13.62(\mathrm{~s}, 2 \mathrm{H}, \mathrm{OH}), 8.65(\mathrm{~s}, 2 \mathrm{H}, \mathrm{CH}=\mathrm{N})$, 7.25 (s, $2 \mathrm{H}, m-\mathrm{H}), 7.22$ (s. $2 \mathrm{H}, m-\mathrm{H}), 3.50$ (br, $2 \mathrm{H}$, cyclohexyl$\mathrm{CH}), 3.40-3.12\left(\mathrm{br}, 32 \mathrm{H}, \mathrm{NCH}_{2}\right), 2.26\left(\mathrm{~s}, 6 \mathrm{H}, \mathrm{CH}_{3}\right), 2.02-1.18$ (br, $158 \mathrm{H}), 0.89\left(\mathrm{t}, J=6.4 \mathrm{~Hz}, 36 \mathrm{H}, \mathrm{CH}_{3}\right) .{ }^{13} \mathrm{C}\left\{{ }^{1} \mathrm{H}\right\} \mathrm{NMR}$ $\left(\mathrm{CDCl}_{3}\right) \delta 165.11,157.73,135.30,131.13,127.09,125.68$, 117.87, 72.13, 59.21, 58.57, 40.11, 38.04, 37.57, 31.94, 29.30, 26.95, 25.08, 23.94, 22.88, 19.82, 17.31, 16.04, 14.40, 13.83. Anal. Calcd. $\left(\mathrm{C}_{132} \mathrm{H}_{254} \mathrm{~B}_{4} \mathrm{~F}_{16} \mathrm{~N}_{6} \mathrm{O}_{2}\right)$ : C, 68.79; $\mathrm{H}, 11.11 ; \mathrm{N}, 3.65 \%$. Found: C, 68.65; H, 11.15; N, 3.42\%.

Complex 17. This compound was synthesized using the same conditions and procedure as complex 12 starting with compound 15. Dark brown sticky solid was obtained in quantitative yield. ${ }^{1} \mathrm{H}$ NMR (DMSO- $\left.d_{6}, 40{ }^{\circ} \mathrm{C}\right) \delta 8.66$ (br, $\left.5 \mathrm{H},\left(\mathrm{NO}_{2}\right)_{2} \mathrm{C}_{6} \mathrm{H}_{3} \mathrm{O}\right)$, $8.03\left(\mathrm{br}, 5 \mathrm{H},\left(\mathrm{NO}_{2}\right)_{2} \mathrm{C}_{6} \mathrm{H}_{3} \mathrm{O}\right), 7.86(\mathrm{~s}, 2 \mathrm{H}, \mathrm{CH}=\mathrm{N}), 7.36(\mathrm{~s}, 2 \mathrm{H}$, $m-\mathrm{H}), 7.27(\mathrm{~s}, 2 \mathrm{H}, m-\mathrm{H}), 6.73\left(\mathrm{br}, 5 \mathrm{H},\left(\mathrm{NO}_{2}\right)_{2} \mathrm{C}_{6} \mathrm{H}_{3} \mathrm{O}\right), 3.67$ (br, 2H, cyclohexyl-CH), 3.30-2.88 (br, 32H, $\left.\mathrm{NCH}_{2}\right), 2.64$ (s, $6 \mathrm{H}, \mathrm{CH}_{3}$ ), 2.06 (br, 2H, cyclohexyl- $\mathrm{CH}_{2}$ ), 1.86 (br, 2H, cyclohexyl- $\left.\mathrm{CH}_{2}\right), 1.72-1.02(\mathrm{br}, 122 \mathrm{H}), 0.86\left(\mathrm{t}, J=6.4 \mathrm{~Hz}, 36 \mathrm{H}, \mathrm{CH}_{3}\right)$. ${ }^{13} \mathrm{C}\left\{{ }^{1} \mathrm{H}\right\}$ NMR (DMSO-d 6 ) $\delta 162.10138 .22,129.81,129.66$, 127.27, 127.05, 124.59, 123.58, 120.01, 116.42, 65.88, 57.93, $57.57,30.27,28.66,25.17,24.26,13.85,13.40,21.61,20.75$, 19.38, 16.56, 13.46, 11.78 .

Complex 18. This compound was synthesized using the same conditions and procedure as complex 12 starting with compound 16. Dark brown sticky solid was obtained in quantitative yield. 
${ }^{1} \mathrm{H}$ NMR (DMSO- $\left.d_{6}, 40{ }^{\circ} \mathrm{C}\right) \delta 8.66\left(\mathrm{br}, 5 \mathrm{H},\left(\mathrm{NO}_{2}\right)_{2} \mathrm{C}_{6} \mathrm{H}_{3} \mathrm{O}\right)$, 8.09 (br, 5H, $\left.\left(\mathrm{NO}_{2}\right)_{2} \mathrm{C}_{6} \mathrm{H}_{3} \mathrm{O}\right), 7.86(\mathrm{~s}, 2 \mathrm{H}, \mathrm{CH}=\mathrm{N}), 7.40-7.32$ (br, $4 \mathrm{H}, m-\mathrm{H}), 6.76\left(\mathrm{br}, 5 \mathrm{H},\left(\mathrm{NO}_{2}\right)_{2} \mathrm{C}_{6} \mathrm{H}_{3} \mathrm{O}\right), 3.47$ (br s, $2 \mathrm{H}$, cyclohexyl-CH), 3.29-2.90 (br, 32H, $\left.\mathrm{NCH}_{2}\right), 2.56\left(\mathrm{~s}, 6 \mathrm{H}, \mathrm{CH}_{3}\right)$, $2.28-1.10(\mathrm{br}, 174 \mathrm{H}), 0.86\left(\mathrm{t}, J=6.4 \mathrm{~Hz}, 36 \mathrm{H}, \mathrm{CH}_{3}\right) .{ }^{13} \mathrm{C}\left\{{ }^{1} \mathrm{H}\right\}$ NMR (DMSO- $\left.d_{6}\right) \delta 162.10138 .22,129.81,129.66,127.27$, $127.05,124.59,123.58,120.01,116.42$, 65.88, 57.24, 55.88, $30.66,28.22,27.92,27.81,25.83,25.24,23.86,22.98,21.57$, 20.51, 13.34, 12.24 .

Compound 20. 1,1-Dimethylethylenediamine (15 mg, 0.17 mmol) and [3-Methyl-5-[ $\left.\left.\left\{\mathrm{Bu}_{3} \mathrm{~N}^{+}\left(\mathrm{CH}_{2}\right)_{3}\right\}_{2} \mathrm{CH}\right\}\right]$-salicylaldehyde $]\left[\mathrm{BF}_{4}\right]^{-}(264 \mathrm{mg}, 0.340 \mathrm{mmol})$ were added into a vial and anhydrous $\mathrm{CH}_{2} \mathrm{Cl}_{2}(3 \mathrm{~mL})$ was added. This solution was stirred overnight over molecular sieves. After filtration over Celite, $\mathrm{CH}_{2} \mathrm{Cl}_{2}$ was removed under vacuum to give a yellow pure solid (236 mg, 96\%). IR (KBr) $3414(\mathrm{OH}), 1628(\mathrm{C}=\mathrm{N}) \mathrm{cm}^{-1} .{ }^{1} \mathrm{H}$ NMR $\left(\mathrm{CDCl}_{3}\right) \delta 14.22(\mathrm{~s}, 1 \mathrm{H}, \mathrm{OH}), 13.53(\mathrm{~s}, 1 \mathrm{H}, \mathrm{OH}), 8.53(\mathrm{~s}$, $1 \mathrm{H}, \mathrm{CH}=\mathrm{N}), 8.49(\mathrm{~s}, 1 \mathrm{H}, \mathrm{CH}=\mathrm{H}), 7.24(\mathrm{~s}, 1 \mathrm{H}, m-\mathrm{H}), 7.21(\mathrm{~s}$, $1 \mathrm{H}, m-\mathrm{H}), 7.19(\mathrm{~s}, 1 \mathrm{H}, m-\mathrm{H}), 7.17(\mathrm{~s}, 1 \mathrm{H}, m-\mathrm{H}), 3.75(\mathrm{~s}, 2 \mathrm{H}$, $\mathrm{NCH}_{2}$-bridged), 3.11 (br, 32H, $\mathrm{NCH}_{2}$ ), 2.26 (s, $6 \mathrm{H}, \mathrm{CH}_{3}$ ), 1.721.20 (br, 76H), 1.04-0.77 (m, 36H, $\left.\mathrm{CH}_{3}\right) .{ }^{13} \mathrm{C}\left\{{ }^{1} \mathrm{H}\right\}$ NMR $\left(\mathrm{CDCl}_{3}\right) \delta 167.41,165.38,157.78,135.53,131.30,127.32$, 125.84, 117.83, 66.00, 66.78, 59.51, 58.74, 54.22, 40.09, 37.32, 37.30, 29.59, 25.72, 24.02, 21.16, 20.09, 19.90, 17.35, 16.07, 16.11, 14.49, 13.87. Anal. Calcd. $\left(\mathrm{C}_{84} \mathrm{H}_{160} \mathrm{~B}_{4} \mathrm{~F}_{16} \mathrm{~N}_{6} \mathrm{O}_{2}\right): \mathrm{C}, 61.77$; H, 9.87; N, 5.15\%. Found: C, 61.72; H, 9.67; N, 5.14\%.

Compound 21. This compound was synthesized using the same conditions and procedure as complex 20 starting using 1,3-diaminopropane. Yield was quantitative. IR $(\mathrm{KBr}) 3437$ $(\mathrm{OH}), 1630(\mathrm{C}=\mathrm{N}) \mathrm{cm}^{-1} .{ }^{1} \mathrm{HNMR}\left(\mathrm{CDCl}_{3}\right) \delta 13.76(\mathrm{~s}, 2 \mathrm{H}, \mathrm{OH})$, $8.44(\mathrm{~s}, 2 \mathrm{H}, \mathrm{CH}=\mathrm{N}), 7.20$ (s, 4H, $m-\mathrm{H}), 3.68$ (br, 4H, $\mathrm{NCH}_{2}-$ bridged), 3.11 (br, 32H, $\left.\mathrm{NCH}_{2}\right), 2.29\left(\mathrm{~s}, 6 \mathrm{H}, \mathrm{CH}_{3}\right), 2.12(\mathrm{~m}, 2 \mathrm{H}$, $\mathrm{CH}_{2}$-bridged), 1.82-1.20 (br, 70H), 0.93 (t, $J=7.2 \mathrm{~Hz}, 36 \mathrm{H}$, $\left.\mathrm{CH}_{3}\right) .{ }^{13} \mathrm{C}\left\{{ }^{1} \mathrm{H}\right\} \mathrm{NMR}\left(\mathrm{CDCl}_{3}\right) \delta 166.03,158.02,135.16,131.05$, 127.38, 125.93, 117.65, 77.43, 59.41, 58.63, 53.73, 40.20, 37.41, 23.98, 19.88, 17.26, 16.08, 13.88. Anal. Calcd. $\left(\mathrm{C}_{83} \mathrm{H}_{158} \mathrm{~B}_{4} \mathrm{~F}_{16}\right.$ $\left.\mathrm{N}_{6} \mathrm{O}_{2}\right)$ : C, 61.56; H, 9.83; N, 5.19\%. Found: C, 61.52; H, 9.85; N, $5.20 \%$.

Compound 22. This compound was synthesized using the same conditions and procedure as complex 20 starting using meso-1,2-diphenylethylenediamine. Yield was 92\%. IR (KBr) $3444(\mathrm{OH}), 1626(\mathrm{C}=\mathrm{N}) \mathrm{cm}^{-1} .{ }^{1} \mathrm{H}$ NMR $\left(\mathrm{CDCl}_{3}\right) \delta 13.30(\mathrm{~s}$, $2 \mathrm{H}, \mathrm{OH}), 8.47(\mathrm{~s}, 2 \mathrm{H}, \mathrm{CH}=\mathrm{N}), 7.29-6.94(\mathrm{~m}, 10 \mathrm{H}), 4.85(\mathrm{~s}$, $\left.2 \mathrm{H}, \mathrm{NCH}_{2}\right), 3.09$ (br, 32H, $\left.\mathrm{NCH}_{2}\right), 2.63\left(\mathrm{~s}, 6 \mathrm{H}, \mathrm{CH}_{3}\right), 1.88$ (br, $2 \mathrm{H}, \mathrm{CH}), 1.82-1.16(\mathrm{br}, 70 \mathrm{H}), 0.93\left(\mathrm{~m}, 36 \mathrm{H}, \mathrm{CH}_{3}\right) .{ }^{13} \mathrm{C}\left\{{ }^{1} \mathrm{H}\right\}$ NMR $\left(\mathrm{CDCl}_{3}\right) \delta 157.52,139.12,135.64,131.51,128.31$, 128.21, 127.52, 125.81, 117.84, 79.83, 77.43, 59.45, 58.69, 57.79, 53.73, 40.06, 23.96, 19.85, 17.26, 16.13, 13.86. Anal.
Calcd. $\left(\mathrm{C}_{94} \mathrm{H}_{164} \mathrm{~B}_{4} \mathrm{~F}_{16} \mathrm{~N}_{6} \mathrm{O}_{2}\right)$ : C, 64.24; $\mathrm{H}, 9.41 ; \mathrm{N}, 4.78 \%$. Found: C, 64.47; H, 9.68; N, 4.98\%.

Complex 23. This compound was synthesized using the same conditions and procedure as complex 12 starting with compound 20. Yield was quantitative. ${ }^{1} \mathrm{H}$ NMR (DMSO- $d_{6}, 40^{\circ} \mathrm{C}$ ) $\delta 8.64\left(\mathrm{br}, 5 \mathrm{H},\left(\mathrm{NO}_{2}\right)_{2} \mathrm{C}_{6} \mathrm{H}_{3} \mathrm{O}\right), 8.03(\mathrm{~d}, J=10.4 \mathrm{~Hz}, 5 \mathrm{H}$, $\left.\left(\mathrm{NO}_{2}\right)_{2} \mathrm{C}_{6} \mathrm{H}_{3} \mathrm{O}\right), 7.35(\mathrm{~s}, 2 \mathrm{H}, \mathrm{CH}=\mathrm{N}), 7.27(\mathrm{~s}, 2 \mathrm{H}, m-\mathrm{H}), 7.23(\mathrm{~s}$, $2 \mathrm{H}, m-\mathrm{H}), 6.69$ (br, $\left.5 \mathrm{H},\left(\mathrm{NO}_{2}\right)_{2} \mathrm{C}_{6} \mathrm{H}_{3} \mathrm{O}\right), 4.06$ (br s, $2 \mathrm{H}, \mathrm{NCH}_{2}$ ), 3.30-2.88 (br, 32H, $\mathrm{NCH}_{2}$ ), 2.67 (s, 3H, $\left.\mathrm{CH}_{3}\right), 2.64$ (s, 3H, $\mathrm{CH}_{3}$ ), 2.52 (s, 6H, $\mathrm{CH}_{3}$ ), 1.80-1.40 (br, 36H, $\mathrm{CH}_{2}$ ), 1.40-1.02 (br, $34 \mathrm{H}), 0.86\left(\mathrm{t}, J=6.4 \mathrm{~Hz}, 36 \mathrm{H}, \mathrm{CH}_{3}\right) .{ }^{13} \mathrm{C}$ NMR (DMSO- $\left.d_{6}\right) \delta$ $164.52,161.17,159.88,131.19,130.16,129.31,129.37,128.13$, $127.99,123.199,70.75,66.21,57.66,57.12,38.65,38.12,28.54$, $23.09,22.95,22.57,18.68,17.47,16.93,16.36,12.86,10.44$.

Acknowledgments. This work was supported by the Korea Science and Engineering Foundation (KOSEF) grant funded by the Korea government (MEST) (No. 2009-0079207) and by Priority Research Centers Program through the National Research Foundation of Korea (NRF) funded by the Ministry of Education, Science and Technology (2009-0093826).

\section{References}

1. (a) S, S.; Min, J. K.; Seong, J. E.; Na, S. J.; Lee, B. Y. Angew. Chem., Int. Ed. 2008, 47, 7306. (b) Seong, J. E.; Na, S. J.; Cyriac, A.; Kim, B.-W.; Lee, B. Y. Macromolecules 2010, 43, ASAP (DOI: $10.1021 / \mathrm{ma} 902162 \mathrm{n}$ ).

2. (a) Liu, B.; Chen, L.; Zhang, M.; Yu, A. Macromol. Rapid Commun. 2002, 23, 881. (b) Hongfa, C.; Tian, J.; Andreatta, J.; Darensbourg, D. J.; Bergbreiter, D. E. Chem. Commun. 2008, 975.

3. Reviews: (a) Luinstra, G. A. Polym. Rev. 2008, 48, 192. (b) Coates, G. W.; Moore, D. R. Angew. Chem., Int. Ed. 2004, 43, 6618. (c) Darensbourg, D. J. Chem. Rev. 2007, 107, 2388.

4. (a) Kember, M. R.; Knight, P. D.; Reung, P. T. R.; Williams, C. K. Angew. Chem., Int. Ed. 2009, 48, 931. (b) Ren, W.-M.; Liu, Z.-W.; Wen, Y.-Q.; Zhang, R.; Lu, X.-B. J. Am. Chem. Soc. 2009, 131, 11509. (c) Noh, E. K.; Na, S. J.; S, S.; Kim, S.-W.; Lee, B. Y.J. Am. Chem. Soc. 2007, 129, 8082. (d) Lee, B. Y.; Kwon, H. Y.; Lee, S. Y.; Na, S. J.; Han, S.-i.; Yun, H.; Lee, H.; Park, Y.-W. J. Am. Chem. Soc. 2005, 127, 3031. (e) Bok, T.; Yun, H.; Lee, B. Y. Inorg. Chem. 2006, 45, 4228. (f) Xiao, Y.; Wang, Z.; Ding, K. Chem. Eur. J. 2005, 11, 3668. (g) Piesik, D. F.-J.; Range, S.; Harder, S. Organometallics 2008, 27, 6178.

5. (a) Na, S. J.; S, S.; Cyriac, A.; Kim, B. E.; Yoo, J.; Kang, Y. K.; Han, S. J.; Lee, C.; Lee, B. Y. Inorg. Chem. 2009, 48, 10455. (b) Yoo, J.; Na, S. J.; Park, H. C.; Cyriac, A.; Lee, B. Y. Dalton Trans. 2010, DOI: 10.1039/b920992a.

6. Min, J.; Seong, J. E.; Na, S. J.; Cyriac, A.; Lee, B. Y. Bull. Korean Chem. Soc. 2009, 30, 745.

7. Hansen, T. V.; Skattebøl, L. Tetrahedron Lett. 2005, 46, 3829.

8. Lu, X.-B.; Shi, L.; Wang, Y.-M.; Zhang, R.; Zhang, Y.-J.; Peng, X.-J.; Zhang, Z.-C.; Li, B. J. Am. Chem. Soc. 2006, 128, 1664. 